Available online at http://journal.ugm.ac.id/ifnp
INDONESIAN FOOD AND NUTRITION PROCRESS

Indonesian Food and Nutrition Progress, 2017, Vol. 14, Issue 2

\title{
Carboxymethyl Celulose (CMC) From Snake Fruit (Salaca edulis Reinw) Kernel of "Pondoh Super": Synthesis and Characterization
}

\author{
Sri Anggrahini ${ }^{1)}$, Djagal Wiseso Marseno ${ }^{1)}$, Agus Setiyoko $^{2)}$, Amalia Wahyuningtyas $^{2)}$ \\ ${ }^{1)}$ Department of Food and Agricultural Product Technology, Faculty of Agricultural Technology, Universitas \\ Gadjah Mada, Jalan Flora No. 1 55281, Yogyakarta, Indonesia \\ ${ }^{2)}$ Postgraduate students of Food Science and Technology, Faculty of Agricultural Technology, Universitas \\ Gadjah Mada Jalan Flora No. 1 55281, Yogyakarta, Indonesia \\ ${ }^{*}$ Corresponding author, e-mail address: sri_anggrahini2006@yahoo.com
}

Received 31 October 2017; Accepted 29 November 2017; Published Online 30 November 2017

\begin{abstract}
Snake fruits kernel has high cellulose content thus potential to be an alternative source of carboxylmethylcellulose (CMC) production. However there are several condition that have to be optimized to increase the CMC synthesis which are concentration of $\mathrm{NaOH}$ solution, NaMCA addition, and the reaction temperature based on the degree of substitution (DS). The aim of this study was to determine the optimum conditions of synthesis CMC from "Salak Pondoh Super" kernel. Some factors that likely influence the synthesis were concentration of $\mathrm{NaOH}$ solution, NaMCA addition, and the reaction temperature based on the degree of substitution (DS) as the responses. Synthesis of CMC was optimized using completely randomized design. The result then was characterized by several parameters including water content, viscosity, purity, Water Holding Capacity (WHC), Oil Holding Capacity (OHC), lightness, crystallinity, and FT-IR spectra. Optimization was achieved by the use of $15 \% \mathrm{NaOH}$ solution, 5 gram NaMCA per 5 gram cellulose and reaction temperature of 55ㄷ. The characteristics of the optimized CMC were DS 0.825 , purity $90.86 \%$, water content of 7.16 (\% wb), viscosity 3.86 cps, 142.72 yield (\% db), WHC 2.37 (g/g), OHC 2.31 (g/g), lightness 78.48, and crystanillity $32.69 \%$. The FT-IR spectra of snake fruit kernel CMC was similar with the CMC Standard.
\end{abstract}

Keywords: cellulose, CMC, "Salak Pondoh Super", kernel

Introduction

Salacca edulis or snake fruit is one of the tropical fruit commodity in Indonesia. Production of snake fruit in Indonesia has been increasing for each year. Data from the Ministry of Agriculture of the Republic Indonesia, the production of snake fruit in Indonesia for the year of 2010, 2011 and 2012 were 749.876 tons, 1.082 .115 tons and 1.035.406 tons, respectively. "Salak Pondoh" is one of the snake fruit variety from Sleman region, Yogyakarta. It has a sweet taste even though the fruit is still young and flowering throughout the year (Santoso, 1999). Salak is a table fruit that only its flesh is consumable. Edible part of the fruit is about $57-69 \%$, while $31-43 \%$ is the waste. The waste source are from its skin and kernel. Snake fruit kernel can be used as alternative source of monosakarida (Nugroho, 2014). Snake fruit kernel was used as coffee like (Anggrahini, et al., 2014; Astuti, 2013) and additionally, snake fruit kernel as a powder was used to absorb $\mathrm{Cr}$ (VI) (Aji and Kurniawan, 2012). Snake skin fruitis believed by many people to have some remarkable properties such as improving 
intelegence, maintaining eye health, treating prostate cancer, repairing pancreas in diabetic patients, preventing high blood pressure and arthritis. But all that still require further research (Kurniawan et al., 2015). According to Supriyadi et al. (2002) the portion of kernel reaches $25-30 \%$ of the total weight of the fruit. If the calculated production of snake fruit in 2012 was 1.035.406 tons, it means the waste of kernel around 260-310 tons, which is a large amount of waste.

From the latest update, it has been found that, snake fruit's kernel has not been utilized into a more useful products with a higher economic value. Snake fruit kernel has high cellulose content-- about $31.10 \%$ (db) (Fathoni, 2014). The snake fruit kernel is a potential source for synthesis of Carboxymethyl Cellulose (CMC) that can be used as food additives because it has functional and good physico-chemical properties, such as high solubility in water, high binding capacity to water, metal ions, oil, as well as its role in decreasing the surface tension of the emulsion system.

Cellulose that has been isolated from snake fruit kernel was then synthesized into $\mathrm{CMC}$ with some different methods. Research was carried out by two steps, i.e. cellulose isolation, followed by synthesis and characterization of CMC. The CMC synthesis includes alkalization and carboxymethylation process. Alkalization was conducted using $\mathrm{NaOH}$ to activate the $\mathrm{OH}$ groups from cellulose, break the hydrogen bonds and develop cellulose molecule thus extend the distance of the cellulose molecule. This process, further on, will facilitate the deployment of cellulosic diffusion of carboxymethylation's reagent, using sodium monocloroacetat. Carboxymethylation and alkalization reaction determine the characteristic of CMC which was obtained with this research. The concentration variations of $\mathrm{NaOH}$ solution, the amount of sodium monocloroacetate, and temperature were studied for the optimization to acquire CMC with a degree of substitution (DS) that is suitable to be used in food industry.

The DS determination was calculated by using completely randomized design. From the obtained optimized $\mathrm{CMC}$, purity and viscosity were characterized afterward. DS determines the solubility of $C M C$ and DS is also a major parameter in food industry. Commercial CMC has a DS of 0,7-0,9. The purity of $\mathrm{CMC}$ determines the quality of the produced CMC. Hence, this research can provide solutions in utilization snake fruit kernel variety "Pondoh" into food additives product which has many uses in the food industry. This research has never been done before, therefore producing biopolymer technology innovation is an expected result so that it can contribute to the advancement of knowledge in terms of the waste utilization into products with

The aim of this study was to determine the optimum conditions of the synthesis of CMC (carboxymethylcellulose) from salak pondoh kernel with synthesis factors i.e. concentration of $\mathrm{NaOH}$ solution, the reaction temperature and NaMCA weight based on DS responses. The studied $\mathrm{CMC}$ quality parameters include water content, viscosity, purity, WHC, OHC, lightness, crystallinity, and FT-IR spectra.

\section{Materials and Methods Materials}

Raw materials used in this research was "Salak Pondoh Super" harvested from Donoasih, Donokerto Village, Turi district, Sleman Regency, Yogyakarta Province, Indonesia. Commercial cellulose, $\mathrm{NaOH}$, $\mathrm{NaOCl}, \mathrm{NaHSO}_{3}, \mathrm{NaMCA}$, Isopropanol and Ethanol Grade Analysis were obtained from Sigma Chemical Co., USA.

\section{Synthesis of Carboxymethyl Cellulose}


Carboxymethyl Cellulose synthesis was done through the following procedure: 5 grams of cellulose powder of pondoh snake fruit kernel was alkalized 25 ㅇ $\mathrm{C}$ for $60 \mathrm{~min}$ in waterbath shaking with $20 \mathrm{ml} \mathrm{NaOH}$ in various concentrations $(5 ; 10 ; 15 ; 20$ and $25 \%)$ in 100 $\mathrm{ml}$ isopropanol as a solvent. After the alkalization process over, it was followed by carboxymethylation with the addition of sodium monochloroasetate (NAMCA) in various amount $(3 ; 4 ; 5 ; 6$ and $7 \mathrm{~g})$ at various temperature $\left(45,50,55,60\right.$ and $\left.65^{\circ} \mathrm{C}\right)$ for 180 min. The slurry was neutralized with $90 \%$ acetic acid and then poured. Sodium carboxy methyl cellulose as residue was washed with ethanol 96\%. The obtained sodium carboxymethyl cellulose was dried at $60^{\circ} \mathrm{C}$ for 30 minutes, grounded and filtered into 60 mesh in size to get $\mathrm{CMC}$.

\section{Characterization of sodium carboxymethyl cellulose}

The moisture content, degree of substitution (DS), and purity of CMC were determined by the ASTM D1439-94 standard method (Anonim, 1994). The water holding capacity (WHC) and oil holding capacity (OHC) were detected by the method of Larrauri et al. (1996).

\section{Water holding capacity (WHC) and oil- holding capacity (OHC)}

Twenty-five milliliters of distilled water or commercial olive oil were added to $1 \mathrm{~g}$ of dry sample, stirred and incubated at $40{ }^{\circ} \mathrm{C}$ for $1 \mathrm{~h}$. After centrifugation, the residue was weighed and $\mathrm{WHC}$ and $\mathrm{OHC}$ calculated as $\mathrm{g}$ water or oil per $g$ of dry sample respectively.

\section{FT-IR spectroscopy of sodium carboxymethylcellulose}

Infrared spectra of the CMC samples were recorded with Shimadzu FTIR-8201. Pellets were made by using $\mathrm{CMC}$ samples ( 3 $\mathrm{mg}$ ) ground with potassium bromide ( 800 $\mathrm{mg}$ ) and transmission was measured at the wavelength number range of $4000-400 \mathrm{~cm}^{-1}$.

\section{Results and Discussion}

The data in Fig. 1 showed that the increase of DS depend significantly on the increase of $\mathrm{NaOH}$. This data suggested that $\mathrm{NaOH}$ had penetrated the cellulose, changed the cellulose crystalline to be amorphous so that the reaction of carboxymethylation could be carried out.

There are three hydroxyl groups available in anhydroglucose for chemical modification. Sodium hydroxide changes the form of cellulose type I to be cellulose type II. The change of cristalinity and poly-morphism maybe due to the partition of sodium hydroxide between the reaction medium and the cellulose chain. This partition occurs when mixture of an organic solvent, water and sodium hydroxide are suspended. However, DS decreases if $\mathrm{NaOH}$ concentration is more than $15 \%$. In higher concentration of sodium hydroxide in the vacinity of the cellulose, will give impact to the substantial change of polymorphism from cellulose type I to cellulose type II during alkalization (Pushpamalar et al., 2006). 
Fig. 1. Surface plot of DS versus $\mathrm{NaOH}$

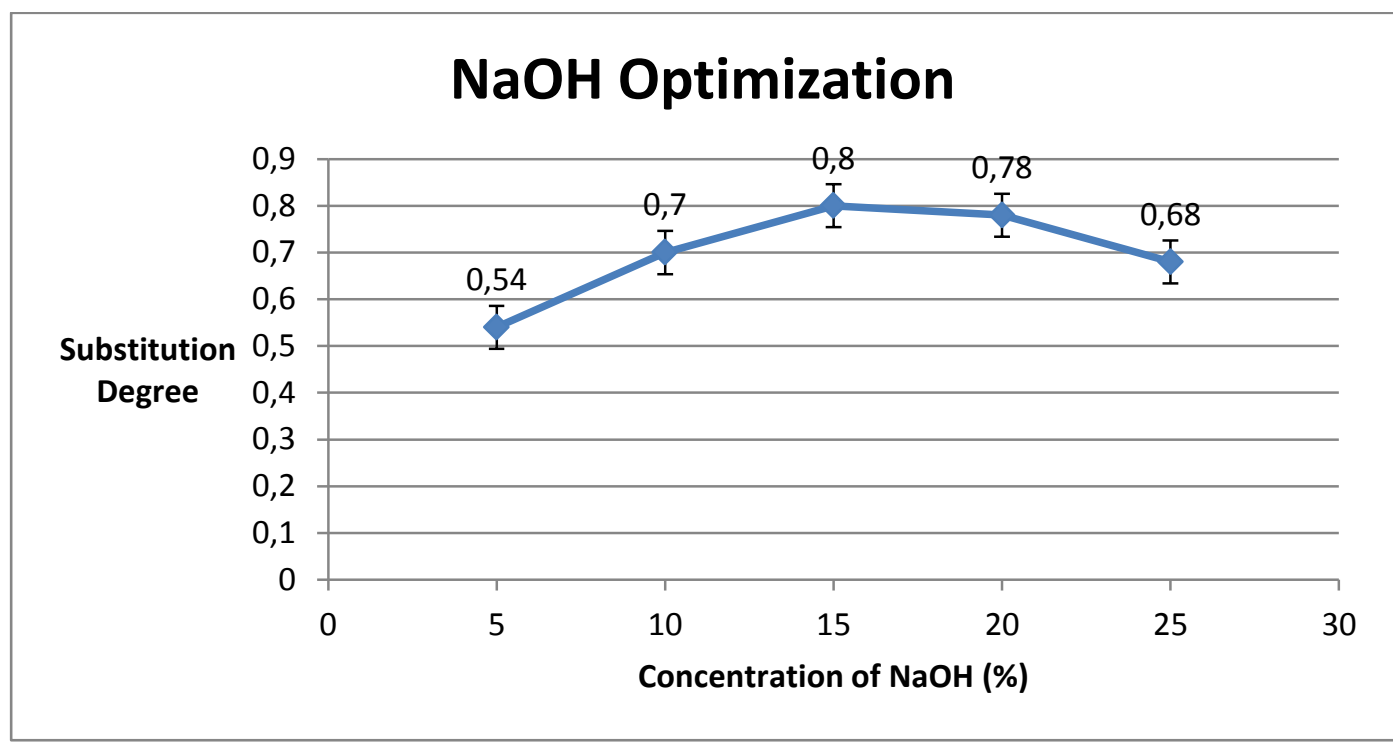

Fig. $\mathbf{2}$ indicated that NaMCA affecting significantly on the increase of DS. However, data in Fig. 1 and Fig.2 showed that the increase of DS was influenced by the increase of $\mathrm{NaOH}$ than the increase of NaMCA. This data suggested that $\mathrm{CMC}$ synthesis was affected by $\mathrm{NaOH}$ where crystalline region in cellulose wouldchange into amorphous region and then atom of $\mathrm{C} 6, \mathrm{C} 2$ and $\mathrm{C} 3$ could be accessed easily by NaMCA in Anhydrous Glucose Unit (AGU) (Olaru et al., 1997). If using NaMCA very high DS to be decrease, it may be due to the production of sodium glycolate.

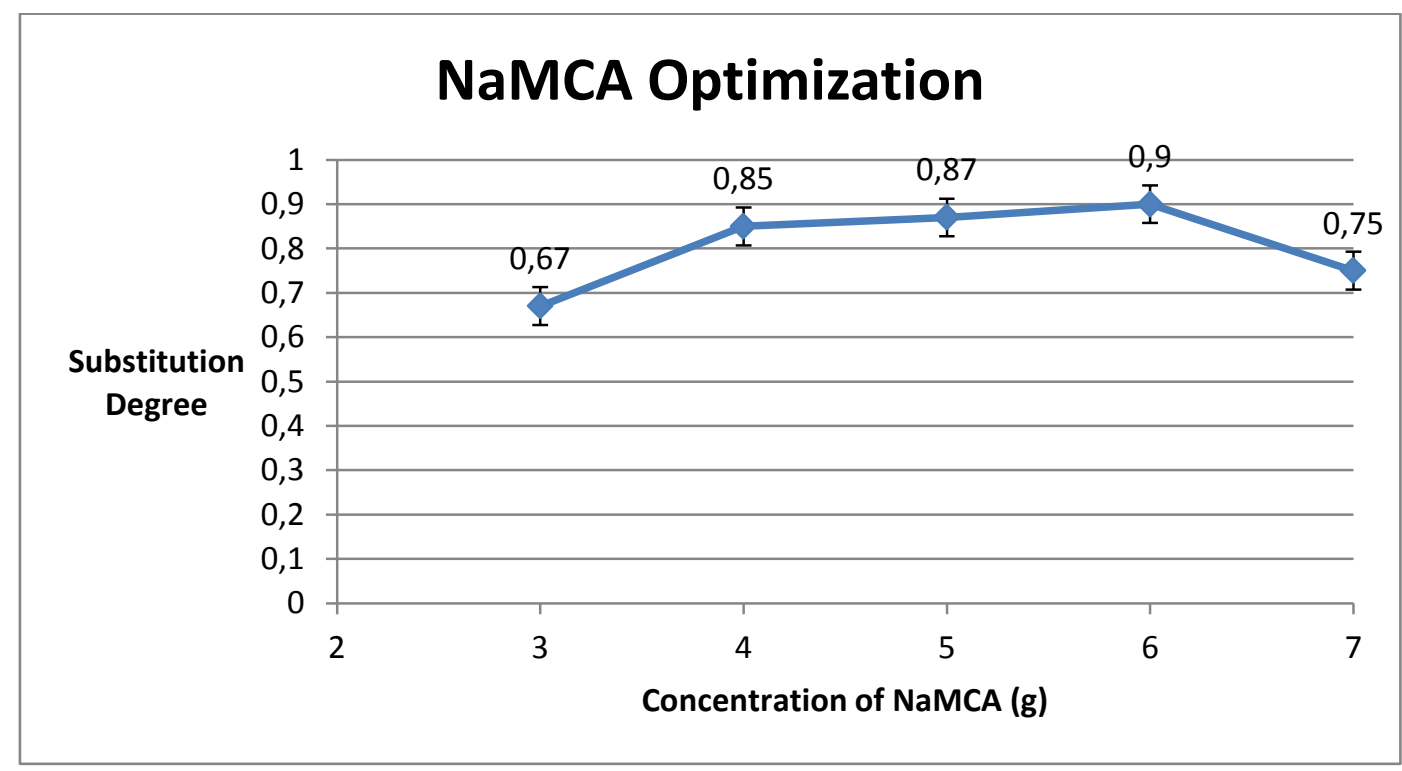

Fig. 2. Surface plot of DS versus NaMCA

In Fig.3, it demonstrated that temperature significantly affected on the increase of DS. Temperature would affect the affinity of the $\mathrm{Na}^{+}$in $\mathrm{AGU}$ in the formation of 
amorphous region and then NaMCA would replace $\mathrm{Na}^{+}$into $\mathrm{CMC}$ in atom $\mathrm{C6}, \mathrm{C} 2$ and $\mathrm{C} 3$. This data was similar to Heinza and Pfeffer (1999). The data concluded that $\mathrm{NaOH}$ concentration, NaMCA weight and temperature were the main factors that affected the synthesis of $\mathrm{CMC}$ similar with previous reports of Heinze and Pfeiffer (1999), Togul et al. (2003) and Pushpamalar et al. (2006).

Optimum condition of CMC synthesis could be simulated by RMS with sodium hydroxyde 15\%, NaMCA $55 \mathrm{~g}$ and at temperature 55ㅇ. The results of $\mathrm{CMC}$ characteristics were as follows, DS: 0.83 , WHC: $2.37 \mathrm{~g} / \mathrm{g}$, OHC: 2.31 g/g, lightness: 78.48 , crystallinity: $32.6 \%$, moisture content: $7.16 \%$, viscosity: 3.86 cpsand purity: 90.86\% (see Table 1).

Table 1. Comparison of the characteristics of seed pondoh CMC and CMC Commercial

\begin{tabular}{|c|c|c|c|}
\hline Characteristics & $\begin{array}{l}\text { CMC Pondoh Snake } \\
\text { Kernel }\end{array}$ & Fruit & CMC Standard \\
\hline DS & 0.83 & & 0.85 \\
\hline WHC (g/g) & 2.37 & & 0.86 \\
\hline $\mathrm{OHC}(\mathrm{g} / \mathrm{g})$ & 2.31 & & 2.55 \\
\hline Lightness & 78.48 & & 8.51 \\
\hline Crystallinity (\%) & 32.69 & & 18.92 \\
\hline Moisture content (\%) & 7.16 & & 9.18 \\
\hline Viscosity (cps) & 3.86 & & 1464 \\
\hline Purity (\%) & 90.86 & & 99.48 \\
\hline
\end{tabular}

In Table 1 indicated that WHC of CMC

Pondoh snake fruit kernel was lower than the $\mathrm{CMC}$ standard. The ability of $\mathrm{NaOH}$ solution which aimed to activate the $-\mathrm{OH}$ group of cellulose molecules had not been effective, thus affecting in diffusion process of NaMCA reagent for carboxymethylation process was inhibited. The process of destruction of crystalline cellulose structure was lower, indicated by the higher crystallinity value of CMC Pondoh snake fruit kernel than CMC standart. It is due to the small amount of amorphous structure of $\mathrm{CMC}$ Pondoh snake fruit kernel, resulting in low water holding capacity. The lightness of CMC pondoh snake fruit kernel was lower than the CMC standard since the purity was also lower. In term of crystallinity, CMC Pondoh snake fruit kernel was more higher than $\mathrm{CMC}$ standard.

Infrared spectroscopy spectra of $\mathrm{CMC}$ with DS 0.83 was showed in Fig. 4. The displacement could be observed from the stretching band of $\mathrm{O}-\mathrm{H}$ which was methylated in C6. Hydroxyl group substitution in C6 significantly changed by rising carbonyl group $(-\mathrm{C}=\mathrm{O})$ in wavelength $1604 \mathrm{~cm}^{-1}$ and $-\mathrm{CH}_{2}$ in wavelength $1419 \mathrm{~cm}^{-1}$. In wavelength $894 \mathrm{~cm}$ 1

,1,4- $\beta$ glycoside of cellulose was detected (Viera et al., 2007). Wavelength $3433 \mathrm{~cm}^{-1}$ was detected due to the stretching frequency of$\mathrm{OH}$ and band 2916 to $2924 \mathrm{~cm}^{-1}$ due to $\mathrm{C}-\mathrm{H}$ streching vibration from AGU (Pescok et al., 1976; Meenakshi et al., 2002).

The peak in wave number $1327 \mathrm{~cm}^{-1}$ was the $-\mathrm{OH}$ peak of AGU stretching vibration. Salt of carboxyl group had wave number about $1600 \mathrm{~cm}^{-1}$ and $1400 \mathrm{~cm}^{-1}$ according to Pescok et al. (1976). Spectra patterns between snake fruit kernel CMC CMC standard were similar. Data of the obtained peaks in FT-IR spectra from CMC constituent was shown in Table 2. 


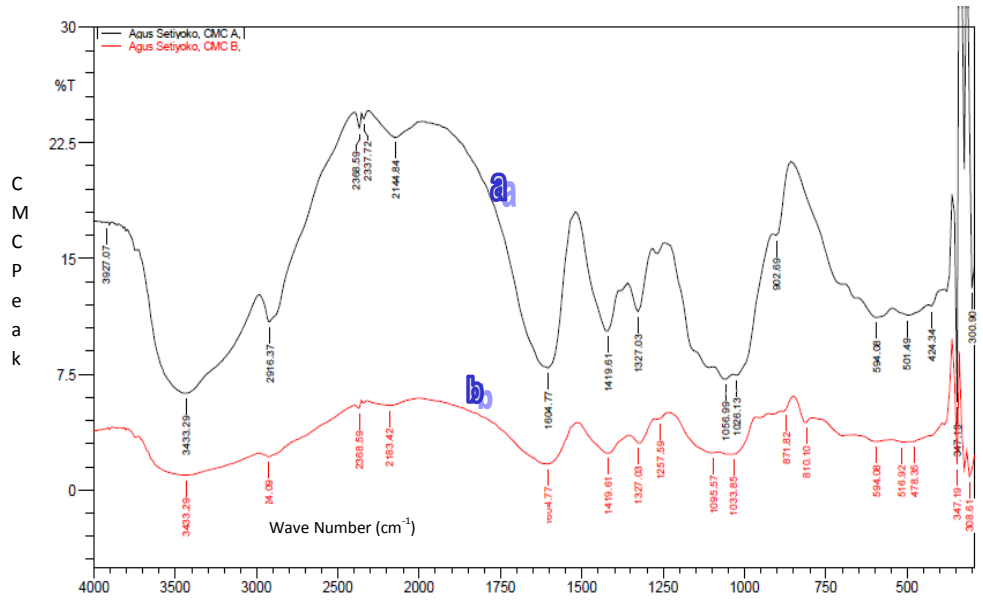

Fig. 4. (a) FT_IR spectra of the CMC standard and (b) CMC of Pondoh snake fruit kernel

Table 2. Assignment of main absorption bonds in $\mathrm{CMC}$ of Pondoh snake fruit kernel

\begin{tabular}{lll}
\hline \multicolumn{2}{c}{ Wave number $\left(\mathrm{cm}^{-1}\right)$} & \multicolumn{1}{c}{ Assignment } \\
\hline CMC & CMC of Pondoh & \\
\hline Standard & Snake fruit kernel & - OH streching \\
\hline-3433 & -3433 & $-\mathrm{CH}$ streching $\mathrm{CH}$ 2 and CH3 group \\
-2916 & -2924 & $-\mathrm{C}=\mathrm{O}$ region (Constituent CMC \\
-1604 & -1604 & $-\mathrm{CH}$ bonding (Constituent CMC) \\
-1419 & -1419 & $-\mathrm{OH}$ Plane Bonding \\
-1327 & -1327 & $-\mathrm{C}-\mathrm{O}-\mathrm{C}$ asymetry bridge streching \\
-1095 & -1056 & $-\mathrm{C}-\mathrm{O}$ asymetry streching Alcohol \\
-1056 & -1056 & $-1-4-$-Bglycoside \\
-902 & -871 &
\end{tabular}

\section{Conclusion}

Isolated cellulose could be modified in 15\% $\mathrm{NaOH}, 5 \mathrm{~g} \mathrm{NMCA}$ and temperature $55^{\circ} \mathrm{C}$, in 3 $h$ for carboxy methyl cellulose which had DS 0.83 . The obtained carboxy methyl cellulose had $2.37 \mathrm{~g} / \mathrm{g}$ of WHC, $2.31 \mathrm{~g} / \mathrm{g}$ of $\mathrm{OHC}, 78.48$ of lightness, 3.86 cps of viscosity, $32.69 \%$ crystallinity, $9.18 \%$ of moisture content, $90.86 \%$ of purity, and yield of 142.72 (\%db). The spectra patternsbetween CMC of Pondoh snake fruit kernel was similar with CMC standard.

\section{References}

Aji, B.K. and F. Kurniawan. 2012. Pemanfaatan Serbuk Biji Salak (Salacca zalacca) sebagai Adsorben $\mathrm{Cr}(\mathrm{VI})$ dengan Metode Batch dan Kolom. Jurnal Sains POMITS. 1 (1): 16.

Anggrahini, S.; Gumawang, A. and Basuki, G. 2014. Pembuatan Minuman Kopi Biji Salak: Kajian Pengaruh Cara Pengeringan, Jenis Biji Salak dan Blending Terhadap Sifat Sensoris, Kimia, Fisika dan Aktivitas Antioksidan. Laporan Penelitian Unggulan Daerah (RUD) Kabupaten Sleman, DIY.

Anonim, 1994. Standar Test Methods for Sodium Carboxy methyl cellulose. ASTM D-1439-94. ASTM Committee on Standards. Philadelphia, USA p 291-298. Astuti, P. 2013. Kopi Nikmat Khas Tapanuli, Terbuat dari Biji Salak. http://life.viva.co.id/news/read/459165.k 
opi-nikmat-khas-tapanuli-terbuat dari-biji salak. Diakses pada 11 Agustus 2016.

Fathoni, F. 2014. Studi Potensi Biji Salak (Salaca edulis Reinw) Sebagai Sumber Alternatif Monosakarida dengan Cara Hidrolisis Menggunakan AsamKhlorida. Skripsi. Fakultas Teknologi Pertanian. Universitas Gadjah Mada.Yogyakarta.

Heinze, T. and Pfeifer, K. 1999. Studies The Synthesis and Characterization of Carboxy Methyl Cellulose. J. Ang. Maeromol. Chem. 266(4638): 37 - 45.

Kurniawan, F., Ulfin, I., Juwono, H., Djarot S.K.S., dan Suprapto. 2015. Diversification of Snake Skin Fruit for Healthy Food. Prosiding Seminar Nasional Kimia, Jurusan Kimia FMIPA, Universitas Negeri Surabaya, 3-4 Oktober.

Meenakshi, P., Noorjahan, S.E., Rajini, R., Venkatesvalu, U., Rose, C., and Sastry, T.P. 2002.Mechanical and Microstructure Study on the Modification of Cellulose Acetate (CA) Film by Blending with Polystyrene (PS) .Bull.Mater.Sci.,25(1):25-29.

Nugroho, A.D. 2014. Studi Potensi Biji Salak (Salacca Edulis Reinw) Sebagai Sumber Alternatif Monosakarida Dengan Cara Hidrolisis Menggunakan Asam Sulfat. Skripsi. Fakultas Teknologi Pertanian. Universitas Gadjah Mada. Yogyakarta.

Olaru, N., Olaru, L., Stoleriu, A., and Timpu, D. 1997. Carboxy Methyl Cellulose Synthesis Inorganic Media Containing
Ethanol and or Acetone. J.App.Polym., Sci.67:481-486.

Pescok, R.L., Shields, L.D., Caims, T., and William I.G.M. 1976. Modern Methods of Chemical Analysis. New York,N.Y. Wiley.

Phuspamalar, V., Langford, S.J., Ahmad, M. and Lim, Y.Y. 2006. Optimization of Reaction Conditions for preparing Carboxy methyl Cellulose from Sago Waste. Carbohydrate Polymers. 64:312318.

Santoso, B.H. 1999. Salak Pondoh. Kanisius. Yogyakarta

Supriyadi, Suhardi, Suzuki, M., Yoshida, K,.Muto, T., Fujita, A., and Watanabe, N. 2002.Changes in the Volatile Compounds and in the Chemical and Physical Properties of Snake Fruit ((Salaca edulis Reinw) Cv. Pondoh During Maturation. Journal of Agricultural Food Chemistry 50 (26):7627-7633.

Togrul, H. and Arslan, N. 2004. Carboxy Methyl Celullose from Sugar Beet Pulp Cellulose as a Hydrophylic Polymer in Coating of Mandarin. Food Engineering, 62:271-279.

Viera, R.G.P., Filho, G.R., Assuncao, R.M.N., Meireles, C.S., Vieira, J.G. and Oliveira, G.S. 2007. Synthesis and Characterization of Methyl Celullose from Sugar Cane Bagas Cellulose. J. Carb. Pol. 67:182-189. 